ISBN - 978-93-86878-33-5

21st PATTAYA International Conference on Agricultural, Environmental and Biological Sciences

(PAEBS-19)

Pattaya (Thailand) Dec. 9-10, 2019

\title{
Diversity and Species Composition of Epiphytic Terrestrial Algae Exposed to Sulphur Dioxide Emissions Released From Power Plant Station
}

\author{
Asmida Ismail ${ }^{1 *}$, Nurul Adibah Mokhtar ${ }^{1}$, Faezah Pardi ${ }^{1}$, Nurul Aida Kamal Ikhsan ${ }^{2}$, \\ Hartini Mahiddin ${ }^{3}$, Khairul Adzfa Radzun ${ }^{1}$, Farah Ayuni Farinordin ${ }^{1}$ \\ ${ }^{1}$ School of Biology, Faculty of Applied Sciences, Universiti Teknologi MARA, \\ 40450 Shah Alam, Selangor, Malaysia. \\ ${ }^{2}$ Centre of Foundation Studies, Universiti Teknologi MARA, Cawangan Selangor, \\ Kampus Dengkil 43800 Dengkil, Selangor. \\ ${ }^{3}$ Biology Department, Center of Applied Science Studies, Universiti Teknologi MARA Cawangan Sarawak, \\ 94300 Kota Samarahan, Sarawak.
}

\begin{abstract}
The availability of pollutants serve as either the nutrient source or a precursor to inhibit some algal species, depending on the types of pollutants. This is the reason why epiphytic terrestrial algae (ETA) is suitable to be used as bio-indicator for air pollution. The objective of this study is to determine species diversity of terrestrial algae near power station with regards of its distance from pollutant source $\left(\mathrm{SO}_{2}\right)$. Terrestrial algae on tree barks were collected near a power plant station at $200 \mathrm{~m}$ to $500 \mathrm{~m}$ from the pollutant source. Tree barks were randomly chosen and 30 quadrats of $15 \times 15 \mathrm{~cm}$ were used. A total of 12 species from 6 families and 9 genera has been identified. Simpson's Diversity Index 1-D (0.841) shows that the species of terrestrial algae distributed were relatively high. Station 1 which is located approximately $200 \mathrm{~m}$ (closest to the pollutant source from the power plant), recorded the greatest species diversity. The Shannon Index ( $\left.H^{\prime}\right)$ value is alsothe highest in Station 1 (1.802) and the lowest value was recorded for Station 2 (1.569). The number of species found in Station 1 is seven with Trentepohlia abietina as the dominant species. Station 2 and Station 3 each recorded six and seven species respectively with Trebouxia sp. as the most diverse species while Station 4 recorded a total of six species with Printzina lagenifera as the dominant species. Trentepohliaceae was found to be the dominant family (40\%) and Trebouxia sp. is regarded as the dominant species which represent approximately $27.59 \%$ of all individuals sampled. From this study, it was found that algal diversity within the study area was not significantly affected by exposure to SO2 released from power plant. However, few common algal species such as Apatococcus sp., Chlorococcum sp., Desmococcus sp. and Trentepohlia rigidula was not recorded at the station nearest to the power plant which was Station 1.
\end{abstract}

Keywords: Diversity, Terrestrial algae, Quadrats, Dominant species, Biological indicator

\section{Introduction}

Sulfur dioxide (SO2) was formerly viewed as the most important phytotoxic pollutant in Europe, and until the early 1980s [1]. Even though the concentration of $\mathrm{SO}_{2}$ in the atmosphere has greatly improved by now, scientists believed that prolonged exposure to $\mathrm{SO}_{2}$ resulted in an alteration of bark $\mathrm{pH}$ which in turn alter the ecosystem landscape [2]. Unlike higher plants, mosses and lichens do not have a protective cuticle exposed to sulfur dioxide which is the major reason for their extreme sensitivity to pollutant [3]. Short duration exposure of 
high concentrations of $\mathrm{SO}_{2}$ produce acute injury in plants while long-term exposure of low concentrations caused chronic injury [4]. $\mathrm{SO}_{2}$ can also modify the response of plants to other environmental stresses, both biotic and abiotic [5]. Since epiphytic terrestrial algae (ETA) is known as an excellent bio-indicator, this study is focussing on the effect of pollutant to the diversity of ETA exposed to prolonged SO2 emissions released from a power plant station. Species diversity were then analysed using Values of Simpson's Diversity Indices, Shannon-Weiner, and Species Evenness.

\section{Method}

\subsection{Algal Specimen Collection}

Samples were collected from tree barks at $200 \mathrm{~m}$ (Station 1), $300 \mathrm{~m}$ (Station 2), $400 \mathrm{~m}$ (Station 3), and 500 $\mathrm{m}$ (Station 4) from the power plant (pollutant source). A number of 10 barks were randomly chosen at each distances with three quadrats of $15 \times 15 \mathrm{~cm}$ on each tree. The quadrats were placed diagonally in line, following the prevailing wind direction from the pollution source. Epiphytic algae within each quadrat were brushed off the surface with a sterilized scalpel from the bark of the tree and put into a $100 \mathrm{~mL}$ specimen vial containing 40 $\mathrm{ml}$ deionized water. All samples were examined as soon as possible. In some cases where immediate examination was not possible, the sample were kept in a refrigerator at a temperature of $4^{\circ} \mathrm{C}$ in the laboratory to prevent post sampling growth.

\subsection{Algal Specimen Identification}

Samples were examined under the digital light microscope (Brunel, UK) with an attached camera for image capturing and species identification. Most algal species were identified by their morphological characteristics. Photomicrographs of the algae were compared to the images from previous studies as references for morphological and anatomical identification [6-7].

\section{Results and Discussion}

\subsection{Species percentage and frequency}

A total of 12 algal species was recorded in all four stations which belongs to 6 families and 9 genera (Figure 1). Trentepohliaceae is the dominant family representing about $40 \%$ of all species collected, followed by Neochloridaceae (26\%), Trebouxiaceae (25\%), Radiococcaceae (6\%), Prasiolaceae (2\%), and Chlorellaceae (1\%). For Trentepohliaceae, Trentepohlia abietina was the most dominant species while Chlorococcum sp. was the dominant species for Neochloridaceae. Trebouxia sp., Gloeocystis sp., Desmococcus sp., and Apatococcus sp. are algal species that belongs to the Trebouxiaceae, Radiococcaceae, Prasiolaceae, and Chlorellaceae respectively. Minute differences in structure and variation of form in populations was difficult to identify particularly as this current study only examined the specimens based on morphological appearance [8]. Figure 1 shows algal species recorded in the sampling stations.

Station 1 which was the closest to the pollutant source at $200 \mathrm{~m}$ recorded a total of 7 species with Trentepohlia abietina as the dominant species while Station 2 and Station 3 which was at 300 and $400 \mathrm{~m}$ from the pollutant source recorded 6 and 7 species respectively with Trebouxia sp. as the most diverse species (Table 1). Station 4 at $500 \mathrm{~m}$ from the pollutant source recorded 6 species with Printzina lagenifera as the dominant species. All four stations are within $500 \mathrm{~m}$ from the power plant, a reachable distance for the wind to carry the pollutants (sulphur dioxide) that provides the necessary nutrients for the survival of Trebouxia sp. Trebouxia sp. is usually found abundance on pollutant-rich stations [9]. 


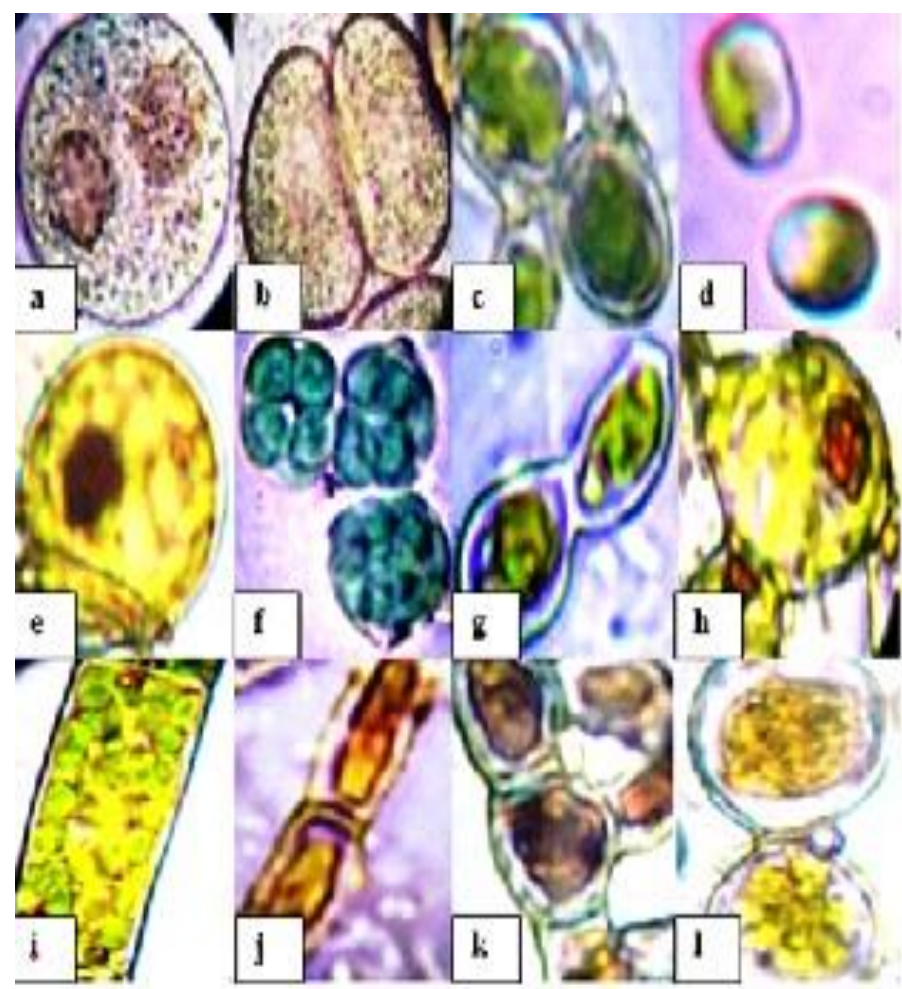

Fig. 1: Algal species recorded in the sampling stations. (a) Trebouxia sp.; (b), Apatococcus sp.; (c), Chlorococcum sp.; (d), Elliptochloris sp.; (e), Neochloris sp.; (f), Desmococcus sp.; (g), Gloeocystis sp.; (h) Printzina diffusa; (i), Printzina lagenifira; (j), Trentepohlia abietina; (k) Trentepohlia maxima; (1), Trentepohlia rigidula.

Another species, Trentehpohlia sp. was found to be more sensitive towards pollutants and is usually only survive when there are fewer sources of pollutants [10]. However the result in this current study conversely showed that Trentepohlia sp. are surviving in most of the stations. Desmococcus sp., the most common green algae in the world [11] only presents at Station 3. Results from this study is in agreement with a study in Singapore where the result showed an insignificant result for Desmococcus $s p$ [9].

TABLE I List of algal species in four sampling stations.

\begin{tabular}{llcccc}
\hline \multicolumn{1}{c}{ Family } & \multicolumn{1}{c}{ Species } & $\begin{array}{c}\mathrm{S} 1 \\
(200 \mathrm{~m})\end{array}$ & $\begin{array}{c}\mathrm{S} 2 \\
(300 \mathrm{~m})\end{array}$ & $\begin{array}{c}\mathrm{S} 3 \\
(400 \mathrm{~m})\end{array}$ & $\begin{array}{c}\mathrm{S} 4 \\
(500 \mathrm{~m})\end{array}$ \\
\hline Trebouxiaceae & Trebouxia sp. & + & + & + & + \\
Chlorellaceae & Apatococcus sp. & - & + & - & - \\
Neochloridaceae & Chlorococcum sp. & - & + & + & + \\
& Elliptochloris sp & - & + & + & + \\
Prasiolaceae & Neochloris sp. & + & - & - & - \\
Radiococcaceae & Desmococcus sp. & - & - & + & - \\
Trentepohliaceae & Printzina diffusa & + & - & - & + \\
& Printzinalagenifira & + & - & - & - \\
& Trentepohlia abietina & + & - & + & + \\
& Trentepohlia maxima & + & - & + & - \\
& Trentepohlia rigidula & + & + & - & + \\
\hline
\end{tabular}




\subsection{Diversity of epiphytic terrestrial algae in sampling stations}

Table 2 showed the indices for epiphytic terrestrial algae collected from the sampling stations. The highest Simpson's Diversity Index 1-D was obtained from Station 1 (0.8089), followed by Station 3 (0.7813), Station 4 (0.7650), and Station 2 (0.7551). From these indices, it can be interpreted that Station 1 which is located about $200 \mathrm{~m}$ from the power plant, has the greatest species diversity of all stations. This station contained highest pollutants concentration as it is closest to the power plant station. The higher the level of pollutants, the higher the nutrients are available for the growth of algae. This indicates that algae which is exposed to higher concentration of pollutant, in this case sulphur dioxide released from the power plant, supported higher species diversity. The Simpson's 1-D value was measured at 0.841 which is considerably high. Shannon (H') is 2.094, showing that species richness of terrestrial algae in this sampling area is also quite high. The Shannon Index (H') is also found to be highest in Station 1 (1.802) with the lowest value recorded in Station 2 (1.569). Data from this index indicates that Station 1 contained the greatest species richness compared to other stations. Meanwhile, species evenness is highest in Station 1 (0.8659) and lowest in Station 3 (0.7989). From the evenness values, it is known that terrestrial algae communities in Station 1 are more evenly distributed compared to Station 3 that has more variation in relative abundance, but not evenly distributed. The value for species evenness is 0.6762 , showing that the terrestrial algal communities have less variation in term of relative abundance of the species.

TABLE II Values of Simpson's Diversity Indices, Shannon-Weiner, and Species Evenness for each sampling station.

\begin{tabular}{llll}
\hline Station & Simpson's 1-D & Shannon $\left(\mathrm{H}^{\prime}\right)$ & Evenness \\
\hline Station 1 $(200 \mathrm{~m})$ & 0.8089 & 1.802 & 0.8659 \\
Station 2 $(300 \mathrm{~m})$ & 0.7551 & 1.569 & 0.8004 \\
Station 3 $(400 \mathrm{~m})$ & 0.7813 & 1.721 & 0.7989 \\
Station 4 $(500 \mathrm{~m})$ & 0.7650 & 1.626 & 0.8476 \\
\hline & 0.841 & 2.094 & 0.6762 \\
\hline
\end{tabular}

The terrestrial algae communities are diverse, which shows that algal diversity was not really affected by the atmospheric condition of the surrounding area. The result is in contrast with the outcome from a previous study which shows that the most polluted station has the highest species diversity of algae [12]. However, climate differences such as tropical and non-tropical surrounding could be a factor in the contrasting result in these two studies.

\section{Conclusion}

Terrestrial algae distributed nearby a power plant station is relatively diverse with a total of 12 species from six families and nine genera. Trentepohliaceae was found to be the dominant family (40\%). Out of 12 species, Trebouxia sp. was the dominating species and represented about $27.59 \%$ of all specimens sampled. The study found that exposure to $\mathrm{SO}_{2}$ released from power plant was not significantly affecting algal diversity within the study area. However, common algal species such as Apatococcus sp., Chlorococcum sp., Desmococcus sp. and Trentepohlia rigidula was not recorded at Station 1 which was the nearest to the power plant.

\section{Acknowledgement}

Authors would like to thank members of Tropical Ecophysiology Research Group (UKM) and staffs of Phycology and Aquatic Plant Laboratory (UKM) for their assistance and guidance upon completing this project. This work was funded under a research grant [600-IRMI/DANA KCM 5/3/LESTARI (119/2017)] awarded from Universiti Teknologi MARA, Shah Alam, Malaysia. 


\section{References}

[1] W. De Vries, J. P. Hettelingh, and M. Posch, Critical Loads and Dynamic Risk Assessments: Nitrogen, Acidity and Metals in Terrestrial and Aquatic Ecosystems, Berlin, Germany: Springer, 2015. https://doi.org/10.1007/978-94-017-9508-1

[2] M. Chrabąszcz, and L. Mroz, "Tree bark, a valuable source of information on air quality," Polish Journal of Environmental Studies, vol. 26(3), pp. 223-228, 2017. https://doi.org/10.15244/pjoes/65908

[3] J. Rahul, and M. K. Jain, "An investigation in to the impact of particulate matter on vegetation along the national highway: A review," Research Journal of Environmental Sciences, vol. 8(7), pp. 356, 2014. https://doi.org/10.3923/rjes.2014.356.372

[4] M. R. Khan, and M. M. Khan,) "Plants response to diseases in sulphur dioxide stressed environment," The Plant Pathology Journal, vol. 10, pp. 1-12., 2011. https://doi.org/10.3923/ppj.2011.1.12

[5] A. Gull, A. A. Lone, and N. U. I. Wani, Biotic and Abiotic Stresses in Plants, London, United Kingdom: Intech Open. 2019. https://doi.org/10.5772/intechopen.85832

[6] P. Milow, and S. Aishah, Epiphytic Terrestrial/Subaerial Algae of the Genera Trentepohlia and Printzina. Kuala Lumpur: Universiti of Malaya Press, 2006.

[7] N. Barton, J. Hermisson, and M. Nordborg, "Population genetics: Why structure matters," Elife, vol. 8, pp. 72-80, 2009. https://doi.org/10.7554/eLife.45380

[8] J. Neustupa, and P. Skaloud, "Diversity of subaerial algae and cyanobacteria growing on bark and wood in the Lowland Tropical Forests of Singapore," Plant Ecology and Evolution vol. 143(1), pp. 51-62, 2010. https://doi.org/10.5091/plecevo.2010.417

[9] D. Kharkongor, and P. Ramanujam, "Diversity and species composition of subaerial algal communities in forested areas of Meghalaya, India," International Journal of Biodiversity, pp. 1-10, 2014. https://doi.org/10.1155/2014/456202

[10] P. Nowicka-Krawczyk, J. Zelazna-Wieczorek, and T. Kozlecki, "Silver nanoparticles as a control agent against facades coated by aerial algae - A model study of Apatococcus lobatus (green algae)," PloS One, vol. 12(8), pp. 272276, 2017. https://doi.org/10.1371/journal.pone.0183276

[11] K. Freystein, M. Salich, M. and W. Reisser, "Algal biofilms on tree bark to monitor airborne pollutants." Biologia, vol. 63, pp. 866-872, 2008.

https://doi.org/10.2478/s11756-008-0114-z 